Rev. ANPOLL, n. 6/7, p. 81-87, jan./dez. 1999

\title{
A INTERTEXTUALIDADE NOS ESTUDOS CLÁSSICOS
}

\author{
Paulo Sérgio de Vasconcellos*
}

RESUMO: Neste brevíssimo artigo, apontamos algumas das questões intertextuais mais relevantes para quem se ocupa do tema nos estudos clássicos. Além da análise dos "lugares-comuns", o estudioso não pode deixar de dedicar atenção ao fenômeno da "arte alusiva", tal como o nomeava Giorgio Pasquali. Do confronto entre o hipertexto e seus vários hipotextos surgem efeitos de sentido, num processo que ultrapassa a noção antiga e tão difundida de imitatio.

PALAVRAS-CHAVE: intertextualidade; poesia latina; arte alusiva.

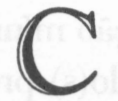

omo se sabe, o termo "intertextualidade" foi pela primeira vez empregado por Julia Kristeva, na década de 60, em seu $\Sigma \eta \mu \varepsilon \iota \omega \tau \imath \kappa \eta$, Recherches sur une sémanalyse; o conceito, nessa obra, abarcava aspectos intertextuais presentes em todo texto "todo texto é absorção e transformação de um outro texto", dizia, mencionando Bakhtin. "Em lugar da noção de intersubjetividade, instala-se a de intertextualidade" (Kristeva: 1974, p. 64). Desde então, tem-se aplicado o substantivo "intertextualidade" e o adjetivo correspondente nos mais diversos contextos, com nuanças várias, a ponto de a noção mesma se tornar algo nebuloso.

A poesia antiga, que é nosso objeto principal de investigação, é "intertextual" em vários níveis, mas se assinala por apresentar marcadamente dois aspectos do fenômeno. Um deles consiste na composição genérica tal como a tem estudado um Francis Cairns: a reelaboração, por determinado poeta, dos lugares-comuns que definem um certo gênero. Sem citar necessariamente o predecessor ou predecessores, um poeta se filia a

* Universidade Estadual de Campinas - UNICAMP. 
VASCONCELLOS, Paulo Sérgio de. A intertextualidade nos estudlos clássicos.

toda uma tradição, tratando de temática considerada típica desse gênero. No plano da forma, um poeta pode extrair da tradição a que se filia e que consiste, em última instância, numa série de textos considerados paradigmáticos, regras que poderíamos chamar, se não for abuso terminológico, "gerativo-transformacionais", que produzirão outros textos reconhecíveis como pertencentes a essa tradição, isto é, como continuadores da retórica desse gênero determinado. Assim, Virgílio escreve como Homero, utilizando símiles, epítetos, estilo formular, cenas típicas etc., mesmo quando não cita explicitamente versos desse modelo arquetípico da epopéia.

Mas um outro aspecto do fenômeno intertextual nos tem sobretudo ocupado nesses últimos anos; é o que talvez seja preferível chamar, com Giorgio Pasquali (Pasquali: 1968, v. II), "arte alusiva", conceito pertinente a toda a poesia greco-latina. Num artigo de 1942, na contramão dos que viam, já desde a $\Lambda$ ntiguidade, na imitação dos autores gregos pelos latinos falta de criatividade ou inferioridade, Giorgio Pasquali concentrou-se na faceta mais sutil desse processo, que vinha recebendo atenção mínima: a criação de sentidos que o diálogo com o(s) texto(s) evocado(s) provoca. Das considerações de Pasquali para os dias de hoje, estamos mais aptos a afirmar a intensidade e a relevância desse jogo alusivo que enriquece a leitura linear, não consciente dos textos evocados.

O exemplo a nosso ver mais patente dessa arte que cria sentidos não-explicitados a partir do confronto com o que poderíamos chamar, com Genette, seus hipotextos, é Virgílio, não por acaso acusado de plágio mais de uma vez na $\Lambda$ ntiguidade e já em sua época. Virgílio pratica a arte alusiva, na acepção em que a definimos, de uma forma notável pela variedade e quantidade de hipotextos que evoca como pela poeticidade e sutileza dos efeitos de sentido que seu texto cria.

Em nossa tese de doutorado, procuramos realizar leituras novas de certos episódios célebres da Eneida partindo do princípio de que, além de suposta homenagem a um precursor, além de marca genérica e filiação a uma tradição poética, a retomada de outros textos, citados com uma ou 
outra modificação, é fenômeno gerador de sentidos, cuja decodificação é deixada à performance do leitor, intérprete mais ativo do que nunca. Não é o caso de retornar a este trabalho; por isso, o que desejamos com esta breve comunicação é esboçar algumas das idéias sobre o tema e incitar a que pesquisadores do campo em nosso meio, estudiosos de latim como de grego, se dediquem a essa faceta crucial da poesia antiga, que ainda nos parece não receber a atenção devida.

Em primeiro lugar, é preciso expandir o foco dos estudos de poesia latina à poesia grega. De fato, desde a $\Lambda$ ntiguidade se discute, preferencialmente, no campo intertextual, a famosa imitatio, a imitação dos modelos gregos pelos romanos, e a correspondente noção de aemulatio: os latinos teriam imitado os gregos para competir com esses modelos, se possível superando-os esteticamente. Ora, já um personagem de Macróbio, nas suas Saturnais (VI, 1, 2), defendendo Virgílio das acusações de plágio, lembrava que os próprios gregos se citavam entre si. Estudos recentes como os de Pucci (Pucci: 1987) vêm apontando curiosos jogos intertextuais até mesmo nas origens da poesia grega, na epopéia homérica. Como mostra esse estudioso, por vezes, quando um texto repete o outro, com eventual modificação, mais que repetição formular, parece estar em jogo um outro fenômeno, que nós chamaríamos de novo "arte alusiva": do confronto entre os contextos surgem efeitos de sentido inegáveis, que o leitor atento ao hipotexto se vê incitado a interpretar.

Seja qual for a resposta - se é possível fornecer alguma - que se der à questão da composição das duas epopéias, o fato é que parece estar em germe nas origens mesmas da poesia ocidental um sutil jogo alusivo que será aprofundado em época alexandrina e intensificado por poetas latinos como Virgílio. Nliás, seria muito interessante, ainda que tarefa extremamente trabalhosa e consumidora de tempo, unir esforços dos especialistas em poesia grega e latina para escrever uma história da poesia greco-latina que contemplasse, sobretudo, o jogo intertextual, desde as origens da poesia grega. Como já ficou evidente hoje em dia, é preciso ir além da pesquisa 
VASCONCELLOS, Paulo Sérgio de. A intertextualidade nos estudos clássicos.

das fontes que, especialmente no século XIX, se forneceu o material comparativo necessário, catalogando citações por vezes exaustivamente, impediu, porém, uma compreensão mais adequada dos aspectos criativos da arte alusiva na poesia, quer grega, quer romana.

Intertextualidade entendida como arte alusiva - eis, pois, uma restrição que fazemos apenas por razões de método: para tornar o conceito mais definido e operacional. Essa "arte" consiste em evocar outros textos através de citação (que pode ser feita de formas tão sutis e diversas que julgamos impossível enumerar objetivamente todos os seus tipos) - e tecer com eles diálogo criador da mais vasta gama de sentidos. Portanto, interessamo-nos, sobretudo, por indícios concretos de evocação textual, tanto mais comprobatórios quanto mais extensos e próximos da "fonte".

Algumas questôes surgem de imediato: primeiramente, a da "intencionalidade". Quando o leitor confronta com o texto os hipotextos e vê surgir daí um efeito de sentido, pode dizer objetivamente que a intenção do poeta era criar o sentido que o leitor explicitou? Aqui, é preciso falar em "intenção da obra", tomando de empréstimo a expressão de que Umberto Eco se tem servido. Pela própria natureza do processo - efeitos que surgem do confronto entre textos, não explicitados, deixados à argúcia e à sensibilidade do leitor - jamais se terá certeza de que o autor o pretendia tal e qual, mas, de resto, a idéia mesma de intencionalidade, nos estudos literários, vem sendo abandonada há algum tempo, com razão. $\mathrm{O}$ fato objetivo é que é difícil resistir às associaçōes a que a obra parece incitar o leitor, sobretudo quando esses efeitos de sentido vêm apoiados por outros elementos do texto.

Uma objeção possível, que emerge quando tentamos mostrar quão rica é uma obra como a Eneida em arte alusiva, uma epopéia que, como se sabe, assemelha-se a uma rapsódia de citações, não apenas de Homero mas de praticamente toda a tradição poética greco-latina: Safo, Eurípides, Sófocles, Ênio, Catulo, Lucrécio etc.: será que o leitor precisa ser assim extremamente culto e refinado (doctus, diria um romano) para perceber 
todas as citações, confrontar contextos evocados e daí tecer associações? Ao invés de simplesmente invocar a educação dos antigos, que em grande parte consistia no aprender de cor os textos poéticos paradigmáticos, bem como o relativo elitismo desse público leitor, preferimos falar em graus de aproximação intertextual num poema como a epopéia virgiliana. Assim, pode-se ler a obra com um mínimo de consciência de seu jogo alusivo, mas tanto mais rica será a leitura quanto mais ativo, no sentido da interpretação intertextual, for o seu leitor.

Por outro lado, como muitos dos hipotextos dos poetas greco-latinos desapareceram com o correr dos séculos, o leitor intertextual "ideal", capaz de reconhecer todas as alusões, é uma utopia tão grande quanto a idéia de um leitor que tivesse, hoje, diante de uma Eneida, as mesmas expectativas que um receptor do mesmo texto na época de Augusto. Sem dar maior valor a isso, a tarefa dos estudiosos é continuar à caça das alusões ou, servindo-se do trabalho filológico já feito, investigar os efeitos poéticos da incorporação das "fontes" em determinado poeta. Aqui, cremos que há muito por fazer, mesmo no caso de uma Eneida, já tão estudada. De fato, se a pesquisa monumental de Knauer (Knauer: 1964), apresenta listagem extensa e minuciosa dos passos retomados de Homero, há ainda a considerar todos os outros hipotextos e, mesmo no caso do estudo mencionado, é preciso dizer que de quando em quando se descobre alguma citação homérica que sua obra não traz (nós mesmos já topamos com isso, que parece, à primeira vista, impossível). Por outro lado, muito do material já revelado, por esse estudioso ou por outros, ainda não foi interpretado com o devido cuidado ou, simplesmente, não foi interpretado.

Por fim, esboçaremos algumas idéias e indagações com as quais nos vimos defrontando desde nossa tese de doutorado. No caso da Eneida, temos visto que, além do diálogo constante com a Ilíada e Odisséia, é muito significativa a retomada "corretiva" de Lucrécio. Já se observou que Virgílio por vezes volta a dar conotação religiosa ao que o poeta epicurista tinha apresentado como fenômeno natural absolutamente desprovido de 
VASCONCELLOS, Paulo Sérgio de. A intertextualidade nos estudos clássicos.

intervenção divina - ou seja, o que Lucrécio "desmistifica", Virgílio "remitifica". Em nossas leituras, temos notado como esse processo é freqüente, levando-nos a crer que o poeta épico, enquanto homenageia o predecessor, "corrige" continuamente uma visão de mundo que a Eneida rejeita. $\mathrm{O}$ tema merece aprofundamento com um trabalho de pesquisa especial.

Outra questão que nos parece relevante: até num poeta popular como Marcial temos encontrado citações de Catulo, Lucrécio, Ovídio, Virgílio. O que de novo nos remete à questão do estatuto do leitor. É preciso verificar que leitor implícito se depreende da análise do jogo alusivo nesse poeta e estudar que nuanças essa estratégia intertextual assume num autor que não suspeitaríamos inclinado a uma técnica refinada e erudita.

Por fim, se descobríssemos entre os antigos a explicitação da faceta do jogo alusivo que mais nos interessa, isto é, a geração de efeitos de sentido, poderíamos afirmar mais convincentemente o que para nós já é convicção - a imitatio é uma arte poética sutil, criadora de sentido, amplamente praticada e especialmente evidente na poesia latina. $\Lambda$ té o momento, só encontramos, nos antigos, referências ao caráter emulativo da imitação e, especialmente, a sua função de ornamento, como se citar um predecessor ilustre significasse nada mais que emprestar algo do seu brilho e excelência ou medir forças com ele. É difícil imaginar que uma rede intertextual tão vistosa como a da Eneida passasse despercebida à crítica antiga do poeta em seu aspecto mais fascinante, ao passo que proliferavam, nos detratores, acusações de plágio e deturpação da excelência do grande predecessor Homero.

Cremos que os temas acima delineados merecem pesquisa mais profunda. Seja como for, nenhum estudioso da poesia greco-latina, sobretudo no âmbito das nossas universidades, pode conceder pouca atenção à arte alusiva como aos fenômenos intertextuais em geral de que vêm se ocupando tantos teóricos de campos diversos do nosso. Aqui, há ainda - nunca é demais ressaltar - muito por fazer. 
Rev. $A N P() L L$, n. 6/7, p. 81-87, jan./dez. 1999

RESUMÉ: Dans cet article très bref on signale quelques-unes ds questions intertextuelles les plus importantes pour ceux qui s'occupent de ce sujet dans les études classiques. Outre l'analyse des "lieux communs", le chercheur doit faire attention au phénomène de l'art allusif, comme il était nommé par (Giorgio Pasquali. De la confrontation entre un hypertexte et ses hypotextes on voit naître des effets de sens, dans un processus qui surpasse la vieille notion si répandue de imitatio.

MOTS-CLÉS: intertextualité; poésie latine; art allusif.

\section{BIBLIOGRAFIA}

KNAUER, Georg. (1964) Die Aeneis und Homer. Göttingen: Vandenhoeck \& Ruprecht.

KRISTEVA, Julia. (1974) Introdução à Semanálise. São Paulo: Perspectiva.

PASQUALI, Giorgio. (1968) "Arte Allusiva” In: Pagine Stravaganti. Firenze: Sansoni, 1968, v. II.

PUCCI, Pietro. (1987) Odysseus Polytropos. Intertextual Readings in the Odyssey and the Iliad. Ithaca and London: Cornell University Press. 